the survey. The records of the Thames Conservancy at Teddington Weir were instanced as one of the few cases of really effective river measurement. In England and Wales, much assistance in regard to stream gauging can be rendered by the Catchment Boards instituted under the Land Drainage Act, 1930.

The investigations of the British Association Committee were briefly described, and Dr. Cunningham then proceeded to review the methods and organisations adopted in certain other countries, namely, Canada, the United States, France, Germany, Switzerland and Italy. A number of lantern slides were exhibited illustrative of typical apparatus and installations in operation in the respective services. It was shown that in all these countries, in addition to rainfall measurement, great importance is attached to the consistent gauging and measurement of riverand stream-flow and to the publication of the results obtained, so as to be accessible by all who are interested.

Dr. Cunningham urged that it should be considered an essential part of the duty of those in charge of a survey to disseminate information and advice to local authorities and others engaged in the exploitation of water supplies and the control of floods. Finally, he said it would largely nullify the value of a survey if it were limited to the mere collection and filing of records and statistics. The keynote of the organisation should be active research.

\section{Fungi of South Australia}

A VERY useful series of handbooks on the flora and fauna of South Australia is prepared by the British Science Guild (South Australia Branch) and published by the Government of South Australia. The editorial committee shows that "there is an admitted lack of inexpensive but accurate books dealing with the plants and animals of South Australia, and it is felt that the absence of such has been a real handicap to young Australia, and so to the progress of Australian Science".

Handbooks on the general flora, mammals, fishes, the building of Australia and the succession of life, crustaceans, and reptiles and amphibians have already been published, while seaweeds, spiders, moths and butterflies, ants and birds are to be described in future volumes. The gratuitous services of recognised authorities on particular subjects have been obtained, whilst the Government of South Australia publishes the volumes at low prices. In spite of the serious depression through which South Australia has been passing, the Government has shown a commendable breadth of vision, and earned the gratitude of all scientific workers by continuing to publish this series.

Part 1 of the handbook on "Toadstools and Mushrooms" before us is by Prof. J. B. Cleland, chairman of the Handbooks Committee, and combines scientific exactitude with a simplicity of statement which should bring the knowledge within reach of any intelligent person. The introductory sections are particularly well written. They deal first with general questions of distribution and activity, and then with uses of fungi, poisoning, fungi and art, localities affected by different species, fungi and bush fires, larger fungi eaten by mammals, insects and other animals, luminescence of fungi, fairy rings, mechanical force exerted by fruiting bodies, methods of collection and preservation, and descriptions of special terms used in classification.

This takes up forty pages of closely-printed text, and the remaining 138 pages are devoted to a general classification of the higher fungi, and to a detailed classification of the Agaricaceæ. The system adopted for the latter combines the orderly, reasoned groupings set forth by Carleton Rea (in "British Basidiomycetæ") with the convenient detail of Claussen's subdivision by spore colour. This combination is used by the foremost students and teachers of mycology in Great Britain. Convenient keys to the species, as well as to the genera, are given.

Thirty-five photographs and drawings and six coloured plates enrich the text, and the price of five shillings is certainly extremely low for such a volume. Copies may be obtained from the Government Printer, North Terrace, Adelaide. British students of mycology can find a wealth of helpful description for many of our native species.

\section{University and Educational Intelligence}

Cambridge.-The Department of Scientific and Industrial Research has offered $£ 2,300$ for building and equipping an extension to the Low Temperature Research Station on its southern side. It is to be used in perpetuity for scientific research and in the first instance for research on problems arising out of the preservation and handling of foodstuffs. In the letter making this offer, it is stated that the Committee of Council has had under consideration the possibility of further extensions of the Station in the future, and that the only areas where such extensions appear to be practicable are at the southern end of the eastern side of the Station and at its north-eastern corner. Having regard to the developments which have taken place since the Station was first erected, the Committee considers it desirable that these two areas should be reserved against future needs.

The Smith's Prizes are awarded to H. G. Booker, of Christ's College, and L. Howarth, of Gonville and Caius College. Rayleigh Prizes are awarded to A. F. Devonshire, of Trinity Hall, T. E. Faulkner, of Gonville and Caius College, and F. Smithies, of St. John's College.

Edinburgh,-The Senatus Academicus has resolved that the honorary degree of LL.D. be offered to the following, for conferment at the Graduation Ceremonial to be held on June 28 :- The Right Hon. Lord Bledisloe of Lydney, Governor-General and Commander-in-Chief of New Zealand; Dr. Nicholas Murray Butler, president of Columbia University, New York; Dr. James L. Garvin, editor of the Observer ; Mrs. M. M. Ogilvie Gordon, geologist, and vice-president of the International Council of Women ; Prof. J. Graham Kerr, regius professor of zoology in the University of Glasgow; Prof. John Laird, regius professor of moral philosophy in the University of Aberdeen ; Sir George Macdonald, formerly secretary of the Scottish Education Department, archæologist, numismatist and historian; Mr. John Donald Pollock, Surgeon-Commander R.N.V.R. medical service during the War; Dr. A. N. Richards, professor of pharmacology in the University of Pennsylvania ; The Hon. Lord St. Vigeans, formerly chairman of the Scottish Land Court. 